\title{
Incorporating Human Rights: Mitigated Dualism and Interpretation in Malaysian Courts
}

\author{
Jaclyn L. Neo'
}

\section{INTRODUCTION}

"If it wasn't crystal clear before today, it is now: the Convention on the Elimination of All Forms of Discrimination Against Women (CEDAW) has the force of law in Malaysia": ${ }^{2}$ the Joint Action Group for Gender Equality (JAG) proclaimed in response to a seminal gender discrimination case decided in 2011. ${ }^{3}$ Following the judgment in Noorfadilla Binti Ahmad Saikin v. Chayed bin Basirun (Noorfadilla), the plaintiff, an aspiring schoolteacher, became the first person to successfully sue the Malaysian government for gender discrimination. The High Court of Shah Alam held that the government violated the plaintiff's constitutional right to equality when it revoked her appointment as a relief schoolteacher. While

$1 \quad$ LL.B (Hons.) (NUS); LL.M (Yale); J.S.D (Yale), Assistant Professor of Faculty of Law, National University of Singapore.

2 Joint Action Group for Gender Equality (JAG), Government Withdraws Appeal; CEDAW Has the Force of Law, WAO (June 27, 2013), http://www.wao.org.my/ news_details.php?nid=299\&ntitle=Government+withdraws +appeal;+CEDAW thas+the+force+of+law. JAG consists of prominent women's groups in Malaysia: Women's Aid Organisation (WAO), All Women's Action Society (AWAM), Perak Women for Women Society (PWW), Persatuan Kesedaran Komuniti Selangor (EMPOWER), Persatuan Sahabat Wanita Selangor (PSWS), Sabah Women's Action Resource Group (SAWO), Sisters in Islam (SIS), Tenaganita, and Women's Centre for Change Penang (WCC).

3 Noorfadilla Binti Ahmad Saikin v. Chayed bin Basirun, [2012] 1 Malaysian Law Journal 832 (Malay.) [hereinafter Noorfadilla]. 
a laudable case and one that significantly advances the cause of women's rights in Malaysia, it was far from clear that the case established CEDAW as binding law in Malaysia. If the statement quoted above means that CEDAW is now binding law that could prevail over all domestic laws and even the constitution, it surely goes too far. But if it means that CEDAW is now a relevant and legitimate source of norms for interpretation, and a highly persuasive one, the statement appositely identifies an important trend towards international engagement in Malaysian courts as well as an erosion of the strict dualist approach to international law. ${ }^{4}$ It is this trend that this article is concerned with.

The starting point of examination is this: Malaysia practices dualism, in line with its British colonial legal heritage. This dualist approach has always formed a critical obstacle to the implementation of international law in Malaysia. Under dualism, international law exists on a different plane from domestic law, and would only be binding and enforceable if it has been directly incorporated on the domestic plane. This has been the accepted position in Malaysia even though the Malaysian constitution does not contain any general statement as to the relationship between international and national law. ${ }^{5}$ The Federal Constitution provides that the federal Parliament has the power to make laws with respect to the implementation of treaties, agreements and conventions, but does not state that implementing legislation is necessary to give effect to international treaties. ${ }^{6}$ Nonetheless, Malaysian courts have conventionally followed a strict dualist approach towards international law. Further, as Shad Faruqi points out, international law is not part of the definition of "law" in Article 160(2) of the Federal Constitution. ${ }^{7}$ Thus, whatever the effect of international human

4 For a closer examination of the case and the use of interpretive incorporation, see Jaclyn Ling-Chien Neo, Calibrating Interpretive Incorporation: Constitutional Interpretation and Pregnancy Discrimination Under CEDAW, 35 Human Rights QUARTERLY 910 (2013).

5 Heliliah Bt. Haji Yusof, Internal Application of International Law in Malaysia and Singapore, 1 Singapore Law Review 62, 63 (1969).

6 See Perlembagaan Persekutuan Malaysia [Malay. Const.] Aug. 31, 1957, art. 74(1).

7 Shad Saleem Faruqi, Human Rights, International Law and Municipal Courts, SUHAKAM, 3 (Oct. 24, 2009), http://www.suhakam.org.my/wp-content/ uploads/2013/12/Human-Rights-International-Law-24.10.09.pdf. 
rights law, it remains on the international plane. In the domestic plane, only the constitution, statutes, and the adopted common law are effective and enforceable in courts.

But there is evidence that this strict dualist stance is changing. In the last decade, there has been a remarkable rise in judicial engagement with human rights law in Malaysia. This coincides with a shift in political attitudes towards greater engagement with international human rights mechanisms. In 1995, Malaysia acceded to CEDAW and the Convention on the Rights of the Child (CRC). In 2010, it also ratified the Convention on the Rights of Persons with Disabilities. In addition, purportedly to demonstrate its commitment to human rights, Malaysia established a human rights commission in 1999 with the stated aim to protect and promote human rights in Malaysia. The Human Rights Commission of Malaysia (Suruhanjaya Hak Asasi Manusia Malaysia or SUHAKAM) has the power to receive complaints and review the government's human rights practices. Its powers are however limited; it does not have the power to invalidate or enforce any laws, or to provide any remedies for complainants. ${ }^{8}$ Nonetheless, despite early skepticism about its independence as well as its ability to review and check governmental abuse, SUHAKAM has generally vindicated itself well enough to draw the ire of the government and applause from human rights activists. ${ }^{9}$

Malaysia's engagement with human rights has also been affected by regional changes. Malaysia is a key player in the Association of South East Asian Nations (ASEAN) and in November 2012, ASEAN countries adopted the ASEAN Human Rights Declaration (AHRD). The declaration is the product of the ASEAN Intergovernmental Commission on Human Rights, established in 2009 under Article 14 of the ASEAN Charter. The AHRD is envisaged as a precursor to a formal human rights treaty for the region. To be sure, the AHRD has been heavily criticized for its abundance

8 For an analysis of Suhakam's early work, see Amanda Whiting, Situating Suhakam: Human Rights Debates and Malaysia's National Human Rights Commission, 39 Stanford Journal of International Law 59 (2003).

9 See Li-ann Thio, Panacea, Placebo, or Pawn? The Teething Problems of the Human Rights Commission of Malaysia (SUHAKAM), 40 GEORge WASHINGTON InTERNATIONAL LAW REVIEW 1271 (2009). 
of caveat and provisos. ${ }^{10}$ It has also been censured for undermining the universal nature of human rights and thereby its capacity to limit governmental overreach. For example, Article 7 entrenches cultural relativism as a permissible constraint on human rights; it states that while all human rights are "universal, indivisible, interdependent, and interrelated," their realization must also take into account "different political, economic, legal, social, cultural, historical and religious backgrounds." ${ }^{\prime 1}$ Furthermore, in many of its articles, the enjoyment of rights is made subject to national laws. ${ }^{12}$ This emphasizes state sovereignty. Taken literally, it could mean that despite the declaration, individual ASEAN member states retain the final say over the scope and content of human rights.

These problems aside, the crucial observation here is that Malaysia's engagement with human rights is arguably becoming more diverse and nuanced. This stands in contrast with its earlier engagement which was dominated by the Asian Values rhetoric, largely developed as a defense to criticism of Malaysia's dismal human rights record. The Asian Values discourse was part of an anti-colonial sentiment and was strongly propounded during Malaysia's "Mahathir era." For Mahathir, human rights were part of a Western imperial enterprise. ${ }^{13}$ In light of globalizing influences where the

10 See, e.g., Yuval Ginbar, Human Rights in ASEAN - Setting Sail or Treading Water?, 10 Human Rights Law Review 504 (2010).

11 Catherine Shanahan Renshaw, The ASEAN Human Rights Declaration 2012, 13 Human Rights Law Review 557 (2013). Many civil society organizations argue that escape clauses such as these provide ready-made justifications for human rights violations by ASEAN states, which is made more egregious by the fact that these states would still be able to flaunt their human rights credentials. See Media Release, Rights Groups Reject Flawed ASEAN Declaration (Nov. 19, 2012), http://www.phuketwan.com/tourism/rights-groups-reject-flawed-aseandeclaration-17082, for media release put out by fifty-three individual human rights groups.

12 Media Release, Rights Groups Reject Flawed ASEAN Declaration, Phuket Wan Tourism News (Nov. 19, 2012), http://www.phuketwan.com/tourism/rightsgroups-reject-flawed-asean-declaration-17082.

13 Mahathir Mohamad, Western Modernism vs. Eastern Thought, in The VoICE of Asia: Two Leaders Discuss the Coming Century 71-86 (Mahathir Mohamad \& Shintaro Ishihara eds., 1995). See generally Eva Brems, Human Rights: Universality and Diversity 82 (2001). But $c f$. Inoue Tatsuo, Liberal Democracy and Asian Orientalism, in The East Asian Challenge for Human Rights 27 (Joanne R. Bauer \& Daniel A. Bell eds., 1999); and Jack Donnelly, Human Rights 
state itself seeks to engage with international human rights mechanisms, this rhetoric of anti-colonial exceptionalism has been superseded for most intents and purposes. Indeed, Malaysia's engagement with CEDAW and the CRC has also generated changes in Malaysia's domestic laws and policy. The 2001 amendment of the constitution to include gender as one prohibited bases for discrimination was clearly directed at fulfilling Malaysia's CEDAW obligations.

This article examines judicial treatment of international human rights law against this backdrop of increased international and regional engagement. It examines how Malaysian courts have used or declined the use of international human rights law in deciding domestic cases. I argue that there is a trend towards greater acceptance of human rights law in Malaysia, and that this leads to a mitigated form of dualism. Part II sets out an analytical framework of strict dualism as being comprised of three legal propositions. Part III examines earlier cases that established and followed a strict dualist position using this analytical framework. Part IV identifies a range of human rights argumentation that Malaysian lawyers have used to challenge the strict dualist position, and judicial reaction to these arguments. It analyzes a divergent line of cases where international human rights law is treated as relevant and even persuasive. It should here be noted that the analysis is not based on any clear periodization of cases; I identify the last decade as significant for the mitigation of a strict dualist approach, but concede that there is no clear and unimpeded trend. While some cases in the last decade have accepted the relevance of international law and suggest openness to superordinating international human rights norms to domestic law, others have fallen back on the strict dualist position. This notwithstanding, Part V contends that the cases taken as a whole indicates a mitigation of a strict dualist approach. Part VI contextualizes these developments and identifies major developments that have influenced the judiciary and the legal profession, who are key actors in this shift towards greater reception towards international human rights law in domestic jurisprudence. On a whole, therefore, this article demonstrates that human rights advocates, through the use of strategic litigation, have

and Asian Values: A Defense of "Western" Universalism, in The East Asian Challenge for Human Rights 60 (Joanne R. Bauer \& Daniel A. Bell eds., 1999). 
been at least somewhat successful in eroding the firm ground on which strict dualism stood in Malaysia.

\section{DUALISM: THREE LEGAL PROPOSITIONS}

Dualism is based on the general notion that international law is a "horizontal legal order based on and regulating mainly the relations and obligations between independent and theoretically equal sovereign States."14 State actions on this horizontal legal order do not have direct or automatic effect on the domestic level. This dualist position contrasts with monist systems, which see international and municipal law as forming part of one and the same continuous legal order. In monist states, treaties are selfexecuting. There is a distinct hierarchy: international human rights law sits at the apex, followed by constitutional law, and then statutes or common law. There is no need for international obligations to be transformed into rules of national law. Furthermore, in cases of conflict in a monist system, international law prevails. ${ }^{15}$

Dualism's insistence on additional and intentional domestication of international law is commonly justified on the basis of the separation of powers. Since the executive is responsible for ratifying treaties whereas the legislature is responsible for making laws, allowing treaties signed by the executive to gain legal status domestically without more would intrude into the legislature's law-making powers. Another common argument proponents of strict dualism often raise are (sometimes exaggerated) fears that having regard to international law in judicial reasoning would encourage judicial activism and undermine the autochthonous nature of domestic law, especially the constitution. ${ }^{16}$

Nonetheless, as Eileen Denza rightly points out, the dualist versus monist dichotomy is often too simplistic. It is not always determinative of,

14 Eileen Denza, The Relationship between International and National Law, in International Law 415, 421 (Malcolm D. Evans ed., 2003).

15 Id. at 421.

16 See Gerald L. Neuman, The Uses of International Law in Constitutional Interpretation, 98 American Journal of InTERnATIONAL LaW 82 (2004); Melissa A. Waters, Justice Scalia on the Use of Foreign Law in Constitutional Interpretation: Unidirectional Monologue or Co-Constitutive Dialogue, 12 Tulsa Journal of Comparative ANd International LaW 149 (2004). 
for instance, a state's constitutional approach to international obligations or how its government will proceed in implementing a new treaty, or even (increasingly) in predicting how its courts will approach complex questions of applicability as they arise in litigation. ${ }^{17}$ Accordingly, it might be more appropriate to consider the monist and dualist approaches as polar opposites on a continuum on which different states stand as being closer to one or the other. The use of monist versus dualist theories remains useful but only as ideal types. State practice however exists on a non-ideal basis and is more complex. It also differs based on the type of international law it encounters. One common distinction is between international treaty law and customary international law. Indeed, even a self-professedly dualist system such as the British legal system treat customary international law as directly applicable in the domestic realm as part of its common law.

Consequently, in order to provide a more nuanced perspective on these divergent approaches, I identify three interrelated propositions that are commonly associated with the dualist position. These propositions provide indicators to determine how far or close a particular state is to the ideal type. First, it is commonly said that under a dualist system, unless directly incorporated, international law is irrelevant to domestic legal developments. I call this proposition "absolute non-relevance." A second position commonly associated with the dualist approach is that international law may be relevant but nonetheless could not override or supersede national statutes and the common law of the state. In the face of a conflict, domestic law prevails. This includes the whole panoply of a country's domestic legislation: its unwritten customs, its common law, written statutes, and constitution. Let us call this domestic law prevails. A third proposition asserts that while international law is relevant, it could not override or supersede the supreme constitution of the state. The relationship between international law and laws of a lower hierarchy than the constitution is indeterminate under this third proposition. This, I denote as the "constitution prevails" proposition.

A strict dualist would simply assert the first proposition of absolute non-relevance of international law and this categorically rejects any reference or consideration of international law. This strict position effectively obviates the second and the third propositions. If international law were strictly regarded as not part of the corpus of law recognized by national

$17 \quad I d$. 
courts, then the question of the relative status of international law with the constitution or domestic laws would not arise at all. International law is entirely outside the contemplation of judges operating on the domestic plane. In contrast, the second and third propositions are less strict in insisting upon the division between international and domestic law. They contemplate the possibility that international law could be relevant, such as where there is a gap in domestic law. Nonetheless, these two propositions remain committed to the primacy of domestic law over international law on the domestic plane. The following sections employ this analytical framework to examine judicial engagement with international human rights law in Malaysia.

\section{JUDICAL ENGAGEMENT WITH INTERNATIONAL HUMAN RIGHTS LAW}

\section{a. International Treaty Law}

Until very recently, strict dualism was the established orthodoxy in Malaysian law. There was absolute non-relevance of international law, except perhaps with respect to customary international law. The relevance of international human rights law was examined in the 1981 case of Merdeka University Berhad v. Government of Malaysia. ${ }^{18}$ This controversial case involved the proposed establishment of a university using Chinese as a medium of instruction. ${ }^{19}$ The government blocked the proposal under the Universities and University Colleges Act 1971. The applicants argued that the refusal to grant them an incorporation order under the statute was unconstitutional and moreover incompatible with Article 26 of the Universal Declaration of Human Rights (UDHR) (which guaranteed equal access to education). Adopting a strict dualist position, the High Court

18 Merdeka Univ. v. Malaysia, [1981] 2 Malaysian Law Journal 356 (Malay.) [hereinafter Merdeka University].

19 Id. 
held that the UDHR was not a legally binding instrument and, in any case, was not part of Malaysian law. ${ }^{20}$

This strict dualist position can still be found in later cases. For instance in the 2005 case of Beatrice a/p At Fernandez v. Sistem Penerbangan Malaysia,${ }^{21}$ the Federal Court appeared to regard CEDAW as a non-relevant source of law in determining whether a contractual clause in a collective agreement constituted pregnancy discrimination in breach of the constitution and of CEDAW. ${ }^{22}$ Under the collective agreement, a pregnant air-stewardess would have to resign from her position, failing which her employer, Malaysian Airlines, would have the right to fire her. The plaintiff, Fernandez, became pregnant but refused to resign. The company terminated her employment. She brought suit, claiming a declaration for reinstatement and damages on the basis that the contract and her termination discriminated on the basis of gender and therefore violated Article 8 of the Federal Constitution. ${ }^{23}$ Fernandez invoked CEDAW to buttress

20 This issue was not addressed on appeal by the Federal Court.

21 Beatrice Fernandez v. Sistem Penerbangan Malay., [2005] 3 Malaysian Law Journal 681 (Malay.) [hereinafter Beatrice Fernandez FC Judgment]; see also Beatrice Fernandez v. Sistem Penerbangan Malay. \& Anor, [2004] 4 Malaysian Law Journal 466 (Malay.) [hereinafter Beatrice Fernandez CA Judgment].

22 The collective bargaining agreement was concluded between Malaysian Airlines System (the employer) and the second respondent, Kesatuan Sekerja Kakitangan Sistem Penerbangan Malaysia (the MAS Employees Union), dated May 3, 1988.

23 Beatrice Fernandez FC Judgment, supra note 21, at 95 23, 26, 28. The plaintiff also raised other arguments pursuant to the Employment Act which specified that female employees are entitled to maternity leave and allowance, provided certain conditions such as length of employment and notice of intended leave of absence are satisfied. The courts rejected the argument, reasoning that the Employment Act only provided for the nature of entitlement but did not expressly prohibit any term and condition of employment that requires flight stewardesses to resign upon becoming pregnant. Neither did it prohibit employers from imposing conditions requiring female employees in specialized occupation such as flight cabin crew to resign if they had become pregnant because they could not work during their pregnancy. Id. 
her constitutional challenge. Notably, Article 11 of CEDAW prohibits pregnancy discrimination.

The Federal Court (as well as the Court of Appeal below it) did not refer to CEDAW or appear to take the relevant CEDAW provisions into account in dismissing Fernandez's case. In its refusal of leave to appeal, the Federal Court only addressed the viability of the questions raised under domestic law and did not address the CEDAW question at all. ${ }^{24}$ Instead, it concluded that the Court of Appeal's judgment did not raise a point of general principle that had not previously decided upon and that Fernandez did not raise a point of such importance in which further argument would be to the public's advantage. ${ }^{25}$ These cases effectively affirm the strict dualist position of absolute non-relevance.

\section{b. Customary International Law}

The status of customary international law in Malaysia is less certain. English law treats customary international law as part of its common law without the need for specific incorporation. Commentators have argued that Malaysian courts should take the same approach and accept customary international law as part of its common law. For instance, Abdul Ghafur Hamid argues that since the English common law is part of Malaysian law (based on section 3(1) of the Civil Law Act), customary international law should ipso facto be recognized as part of Malaysian law. ${ }^{26}$ However, since section 3 of the Civil Law Act only required courts in Malaysia to apply the common law and the rules of equity as administered in England on April 7, 1956, there remains a question of whether customary international law developed post 1956 could have direct application in Malaysian law.

The one subject matter where this has arisen for consideration is in the doctrine of state immunity. The older rule under customary international law asserted the absolute immunity of the state. This later evolved to a restricted form of state immunity. The older rule had been applied

$24 \quad$ Id. 11.

25 Id. 99 9-10.

26 Abdul Ghafur Hamid \& Khin Maung Sein, Judicial Application of International Law in Malaysia: An Analysis, The Malaysian Bar (Mar. 31, 2006), http://www. malaysianbar.org.my/international_law/judicial_application_of_international_ law_in_malaysia_an_analysis.html\#f21. 
in English courts and was thereby part of the common law. ${ }^{27}$ Thus, the doctrine of absolute immunity was similarly applicable in Malaysia. ${ }^{28}$ The question of whether to accept the limited state immunity doctrine came up for consideration in the 1990 case of Commonwealth of Australia $v$. Midford (Malaysia) Sdn. Bhd. ${ }^{29}$ Significantly, the Supreme Court decided in the affirmative.

While this case could suggest that Malaysian law is receptive to customary international law, the incorporation process appears to still be mediated through English common law. It should be noted that the English Court of Appeal, under Lord Denning's leadership, had accepted the newer rule of restricted immunity in the 1977 case of Trendtex Trading Corporation Ltd v. Central Bank of Nigeria. ${ }^{30}$ According to the English Court of Appeal, English courts could give effect to changes in customary international law without an act of parliament. ${ }^{31}$ It was this change in common law that the Malaysian Supreme Court relied upon to adopt the newer rule of restricted immunity. As the court puts it:

When the Trendtex case [1977] 2 WLR 356; [1977] 1 All ER 881 was decided by the UK Court of Appeal in 1977, it was of course for us only a persuasive authority, but we see no reason why our courts ought not to agree with that decision and rule that under the

27 E.g., The Parlement Belge, [1879] 4 P.D. 129 (Eng.).

28 See, e.g., Village Holdings Sdn.Bhd. v. Her Majesty the Queen in Right of Can., [1988] 2 Malaysian Law Journal 656 (Malay.).

29 Australia v. Midford (Malay.) Sdn. Bhd, [1990] 1 Malaysian Law Journal 475 (Malay.) [hereinafter Australia v. Midford].

30 Trendtex Trading Corp. v. Cent. Bank of Nigeria, [1977] Q.B. 529 (Eng.) [hereinafter Trendtex]. See also Denza, supra note 14, at 428-29.

31 Although this gives effect to customary international law, the Court of Appeal was also criticized for having been speculative in asserting that there had been a definitive change in the customary international rule on state immunity. ERNEST K. Bankas, State Immunity Controversy in International Law: Private Suits Against Sovereign States in Domestic Courts 105-11 (2005). In dissent, Judge Stephenson (Stephenson, A.L.J.) argued that there was insufficient evidence that a new customary international rule had been fully developed such that it is binding on all nations. 
common law in this country, the doctrine of restrictive immunity should also apply. ${ }^{32}$

This begs the question of whether the Malaysian courts could develop the common law to take into account new rules of customary international law, independently of developments in English common law. I would argue that Malaysian courts do have the authority to do so and should do so as part of its obligations as a member of the international community.

This possible acceptance of customary international law as directly applicable as part of the common law in Malaysia however remains within dualist thinking. This is because such customary international, as part of the common law, are still subject to statutory law as well as the constitution. Consequently, where there is a conflict between customary international law and domestic statutory or constitutional law, it is the latter that prevails. Indeed, theSupreme Court in Australia v. Midford was careful to clarify that this common law position "could well be superseded and changed by an Act of Parliament later on should our legislature decide to define and embody in a statute the limits and extent of sovereign immunity in this country." 33 Thus while customary international law could be a relevant source of law, and could arguably be used to change the common law, it could not override statutory law where there is a conflict. Domestic law and constitutional law would prevail.

This position is consistent with an earlier 1987 case of PP v. Narongne Sookpavit. ${ }^{34}$ The case concerned a group of Thai fishermen who were arrested off the coast of Johor and charged for being in possession of fishing appliances in contravention to Malaysia's Fisheries Act 1963. The accused persons raised as part of their defense the right of innocent passage. They argued that such right was part of customary international law, and thereby part and parcel of Malaysian law.

The court accepted the possibility that customary international law could be relevant in domestic adjudication, but rejected the accused persons'

\footnotetext{
32 Australia v. Midford, supra note 29, at 480.

33 Id.

34 Pub. Prosecutor v. Narongne Sookpavit, [1987] 2 Malaysian LaW Journal 100 (Malay.).
} 
arguments on the basis that Malaysian domestic law would nonetheless prevail. It reasoned:

Even if there was such a right of innocent passage and such right was in conformity with customary English law or customary international law as it is applied in England, the passage by the accused person in the circumstances of this case could not be regarded as innocent passage since it contravened Malaysian domestic legislation. ${ }^{35}$

This case does not provide certainty as to whether customary international law is directly applicable in Malaysia, even as part of adopted common law. However, it does establish that even if relevant, customary international law would nonetheless have limited effect and remain subject to domestic law.

\section{THE RISE OF HUMAN RIGHTS ARGUMENTATION AND THE EROSION OF THE STRICT DUALIST POSITION}

\section{a. Three Types of Human Rights Argumentation}

In Malaysia, the dualist position has been increasingly challenged in recent years due to rising engagement by litigants, and thereby the courts, with international human rights norms. Broadly, three types of arguments have been used to invoke international human rights law in domestic courts. The first posits that the Universal Declaration of Human Rights has been statutorily incorporated. This is based on section 4(4) of the 1999 Human Rights Commission of Malaysia Act (SUHAKAM Act), which provides that the commission shall have regard to the UDHR, particularly in performing its functions and powers. Litigants have argued that this effectively incorporated the UDHR into Malaysian law.

The second type advocates the doctrine of legitimate expectation. According to this doctrine, citizens have a legitimate expectation that the government will not act inconsistently with their treaty obligations. Now, it is a widely accepted rule of interpretation, even in dualist systems, that courts should, as far as possible, interpret constitutional provisions and statutes in conformity with a state's treaty obligations. The justification for this is that it is reasonable for courts to assume that the state intends to comply with its treaty obligations. The doctrine of legitimate expectation

Id. (emphasis added). 
however extends this rule of interpretation to give individuals the right to effectively enforce the treaty domestically. ${ }^{36}$ There is some disagreement as to whether this translates into a procedural or a substantive right. In the seminal case of Minister of State for Immigration and Ethnic Affairs v. Ah Hin Teoh, the High Court of Australia recognized this doctrine of legitimate expectation on the basis that:

$[R]$ atification of the convention is a positive statement by the executive government of this country to the world and to the Australian people that the executive government and its agencies will act in accordance with the convention. That positive statement is an adequate foundation for a legitimate expectation, absent statutory or executive indications to the contrary, that administrative decision makers will act in accordance with the convention. ${ }^{37}$

This is however, according to the Australian High Court, limited to a procedural right. Chief Justice Mason and Justice Deane observed in their combined judgment that the existence of a legitimate expectation does not necessarily compel a decision-maker to act in a particular way. This, they clarify, is the difference between a legitimate expectation and a binding rule of law. What it does require is that if a decision-maker proposes to make a decision inconsistent with a legitimate expectation, procedural fairness requires that the persons affected should be given notice and an adequate opportunity of presenting a case against the taking of the course. In comparison, leading Malaysian constitutional lawyer Malik Imtiaz Sarwar has proposed a doctrine of legitimate expectation that goes beyond procedural fairness. Not only is it sometimes difficult to separate the procedural from the substantive, he argues that, in certain situations, the expectation created could be a substantive right, such as where constitutional safeguards

36 For discussion on the doctrine of legitimate expectations, see Malik Imtiaz Sarwar, Representations by Governments and Legitimate Expectations: A Means to the Enforcement of International Norms in Domestic Courts, The Malaysian BaR (Jan./Feb. 2004), http://www.malaysianbar.org.my/human_rights/representations _by_governments_and_legitimate_expectations_a_means_to_the_enforcement_ of_international_norms_in_the_domestic_courts.html.

37 Minister of State for Immigration \& Ethnic Affairs v. Ah Hin Teoh, [1995] 128 Australian Law Reports 353 (Austl.). 
are implicated. ${ }^{38}$ Under such circumstances, the nature and extent of the relief available could be (and should be) substantive. ${ }^{39}$

The third type of argument entails using international human rights law as an interpretive source. This is part of a broader movement within the commonwealth where judges have increasingly sought to take international human rights law into account in their judicial reasoning. This emerging approach was given expression in the so-called Bangalore Principles, which identified a "growing tendency for national courts to have regarded to ... international norms for the purpose of deciding cases where the domestic law - whether constitutional, statute or common law - is uncertain or incomplete." ${ }^{40}$ What is especially significant is the declared propriety of doing so. The Bangalore Principles stated:

It is within the proper nature of judicial process and well established judicial functions for national courts to have regard to international obligations which a country undertakes - whether or not they have been incorporated into domestic law - for the purpose of removing ambiguity or uncertainty from national constitutions, legislation or common law. ${ }^{41}$

This rejects a strict dualist position, which would regard international norms as irrelevant to domestic courts. Nonetheless, the 1988 Bangalore Principles remained circumspect; principle 8 clarified that "where national law is clear and inconsistent with the international obligations of the State concerned in common law countries the national court is obliged to give effect to national law." 42 In such cases, the court's main role would be to draw attention to such inconsistency so that the legislature and the executive could take steps to rectify the situation which would be a breach of the state's international obligations.

Of these three types of arguments, it is the last type, i.e. interpretive incorporation, which has been the most successful in Malaysia. The landmark case for this is the Noorfadilla case mentioned in the introduction.

38 Sarwar, supra note 36.

39 Id.

40 Bangalore Principles, in Commonwealth Secretariat, Developing Human Rights Jurisprudence: The Domestic Application of International Human Rights Norms ix (1988) [hereinafter 1988 Bangalore Principles].

$41 \quad$ Id.

$42 \quad I d$. 
Nonetheless, Noorfadilla must be seen as part of a line of cases where the strict dualist position has been increasingly challenged by these three types of argumentation.

\section{b. Effective Statutory Incorporation}

On the first, although the Malaysian courts have expressly rejected the effective statutory incorporation argument their treatment of this argument demonstrates a mitigation of the strict dualist position which sees international law as simply irrelevant. For instance, in the 2002 case of Mohamad Ezam bin Mohd Noor v. Ketua Polis Negara, the Federal Court specifically addressed and rejected the argument that the UDHR has been effectively incorporated. ${ }^{43}$ However, it also threw open the possibility that an international treaty (as opposed to a declaration) could be regarded differently.

In this case, the Federal Court was asked to consider the relevance of international law in defining the substantive right to counsel under the Federal Constitution's Article 5(3). The appellants had been detained without trial and were denied access to counsel during their detention. They applied for habeas corpus. The Federal Court decided in the detainees' favor, holding that the order of detention was mala fide (made in pursuant of a political agenda rather than on grounds of national security). An argument was made that the court should have regard to international standards in determining the scope and meaning of Article 5(3) of the Federal Constitution. More specifically, the effective incorporation argument was advanced. Counsel argued that the approach taken by international community as manifest in various United Nations' documents on the subject of legal representation had received statutory recognition by the passing of the SUHAKAM Act. The Federal Court did not accept this argument. Addressing the relevance of the UDHR, Siti Norma Yaakob FCJ opined that the status and weight to be given to the UDHR remained unchanged even after the SUHAKAM Act. Her Honour reasoned that section 4(4) only provides for reference (or regard) to the UDHR which indicates "an invitation to look" at it "if one is disposed to do so" 44 and to

43 Mohamad Ezam bin Mohd Noor v. Ketua Polis Negara, [2002] 4 Malaysian LaW Journal 449 (Malay.) [hereinafter Mohamad Ezam].

44 Id. at 514 (emphasis added). 
"consider the principles stated therein and be persuaded by them if need be." 45 It does not oblige or compel adherence. The courts are not required to consider UDHR principles if they do not wish to. Therefore, it could not be said that the SUHAKAM Act had effectively incorporated the UDHR into Malaysian law.

This judicial refusal to accept that the UDHR has been incorporated into Malaysian law, and is thereby a binding source of law is premised on three reasons. First, reliance was placed on the declaratory nature of the UDHR. Since declaratory principles do not have any force of law or binding effect on member states in any case, Her Honor observed:

If the United Nations wanted those principles to be more than declaratory, they could have embodied them in a convention or a treaty to which member states can ratify or accede to and those principles will then have the force of law. ${ }^{46}$

The second reason is that section 4(4) was in any case qualified; it states that regard shall be had but only "to the extent that it is not inconsistent with the Federal Constitution." ${ }^{47}$ Lastly, the judge opined that it was not necessary to refer to the UDHR because Malaysia's “own laws backed by statutes and precedents" were sufficient to deal with the issue of access to legal representation. ${ }^{48}$

Considering that the court decided to uphold the right to legal representation in this case, thereby producing a pro-rights outcome, this refusal to take into account UDHR principles was not determinative of the result. However, the relevance of UDHR principles could theoretically be more determinative in other cases. What is significant about this case is that it opens the door to the possibility of mitigating the earlier strict dualist position. The Federal Court did not consider the Merdeka University case strictly applicable because it was decided prior to the passing of the SUHAKAM Act. ${ }^{49}$ Implicit in the reasoning is an important concession that the UDHR could be a relevant source of legal norms for constitutional interpretation. This must be considered significant not least because section

\begin{tabular}{ll}
\hline 45 & $I d$. \\
46 & $I d$. \\
47 & $I d$. \\
48 & $I d$. \\
49 & $I d$. at 514B.
\end{tabular}


4(4) of the SUHAKAM Act only directs the human rights commission, and not the judiciary, to have regard to the UDHR in performing its functions and powers. The judge's acceptance that section 4(4) permits judges to have regard to the UDHR is an important extension of the scope of the provision. It is also an acceptance that judges do play a role in upholding human rights in Malaysia. Furthermore, the judgment appears to leave open the question of whether the Federal Court would take a different position and accept an international human rights convention (i.e. a binding treaty) as being persuasive or even binding law in Malaysia.

\section{c. The Limits of the Doctrine of Legitimate Expectation}

Although the doctrine of legitimate expectation has made inroads in Australia, it has yet to be explicitly accepted as part of Malaysian law. The doctrine was considered and rejected in the 2010 case of SIS Forum (Malaysia) v. Dato' Seri Syed Hamid bin Syed Jaafar Albar (Menteri Dalam Negeri) ${ }^{50}$ and the 2012 case of Sepakat Efektif Sdn Bhd v. Menteri Dalam Negeri Malaysia. ${ }^{51}$ In SIS Forum, the applicants challenged a ministerial decision to the ban a book it publishes titled Muslim Women and the Challenges of Islamic Extremism. The book was a compilation of essays submitted at an international meeting entitled "International Round Table on Muslim Women and the Challenge of Religious Extremism: Building Bridges between Southeast Asia and the Middle East" and had been in circulation for several years before the prohibition order was made under section 7(1) of the Printing Presses and Publications Act 1984. Relying on a determination by the Department of Islamic Development (Jabatan Kemajuan Islam Malaysia) that the book has the tendency to confuse Muslims, particularly Muslim women, the Minister issued the ban on the ground that the book was "prejudicial to public order." The High Court decided for the publisher, holding that a tendency to confuse Muslims did not amount to being prejudicial to public order.

The applicants argued that they had a legitimate expectation that "they will not be discriminated against on the basis of gender or religion and

50 SIS Forum (Malay.) v. Dato' Seri Syed Hamid bin Syed JaafarAlbar (Menteri Dalam Negeri), [2010] 2 Malaysian LaW Journal 378 (Malay.) [hereinafter SIS Forum].

51 Sepakat Efektif Sdn. Bhd. v. Menteri Dalam Negeri Malay., [2012] 9 Malaysian LaW Journal 550 (Malay.) [hereinafter Sepakat Efektif]. 
that their freedom of expression will only be curtailed by the Malaysian government in accordance with international human rights norms" 52 To support their argument, they relied not only on the UDHR but also on CEDAW, to which Malaysia is a party. Reference was also made to the 1988 Bangalore Principles' exhortation "to have regard to international obligations which a country undertakes ... for the purpose of removing ambiguity or uncertainty from national constitutions, legislation, or common law." ${ }^{53}$

Sepakat Efektif similarly concerned a ministerial decision restricting free speech rights. Here, the Minister of Home Affairs had banned three books with political content for being prejudicial to public order. In addition to raising arguments that the ban violated their constitutional rights, the applicants also made reference to the UDHR. The applicants argued that the doctrine of legitimate expectation required the government to instruct the Minister to observe its obligations under the UDHR. ${ }^{54}$

There were divergent outcomes in the two cases. The High Court of Kuala Lumpur, which decided both cases, ruled in the applicants' favor in SIS Forum but dismissed the applicants' case in Sepakat Efektif. Nonetheless, both courts treated the argument based on legitimate expectation in the same way. In both cases, the High Court rejected the doctrine of legitimate expectation, highlighting that the law set out in Minister of State for Immigration and Ethnic Affairs v. Ah Hin Teoh (discussed above) is controversial even in Australia. ${ }^{55}$ Instead, the Merdeka University strict dualist approach whereby the "the Malaysian courts [do] not directly accept norms of international law unless they are incorporated as part of our municipal law" was affirmed. ${ }^{56}$

Of the two, SIS Forum deserves slightly more attention because the status of CEDAW was put to question in the case. Regrettably, the High Court did not address the distinction made earlier by the Mohamad Ezam court between declaratory texts and ratified treaties. This lack of attention to the differing nature of the two types of documents contrasts with the

\footnotetext{
52 SIS Forum, supra note 50, at 23.

$53 \quad I d$.

54 Sepakat Efektif, supra note 51, at $\mathbf{3 0 .}$

55 Id. 933.

56 SIS Forum, supra note 50, at 37; Sepakat Efektif, supra note 51, at 33 (emphasis added).
} 
approach taken by the High Court in Noorfadilla. There, the High Court clearly relied on this distinction to buttress its reliance on CEDAW principles. In light of Noorfadilla and, indeed since the High Court here did not fully address the distinction the Federal Court accepted in Mohamad Ezam, it is arguable that the applicability of human rights treaties remains open for consideration in the context of the doctrine of legitimate expectation.

This is especially in light of the High Court of Ipoh's judgment in Indira Gandhi a/p Mutho v. Pengarah Jabatan Agama Islam Perak. ${ }^{57}$ The case concerned the validity of unilateral conversion of minors to Islam by one parent, without the consent of the other. This is a seminal case as the High Court decisively held that the conversion was invalid because it violated the non-consenting parent's constitutional rights of freedom of religion, rights of guardianship, and guarantee of equal protection. The doctrine of legitimate expectation (based on Teoh) was again raised, in addition to the argument of effective incorporation of the UDHR based on the SUHAKAM Act. In addition to the UDHR, the applicant also relied on CEDAW and CRC.

The High Court in Indira Gandhi essentially accepted that Malaysia's international commitments evidenced by its ratification of human rights treaties and affirmations of its obligations contained therein imposed on Malaysia a legal obligation (on the domestic plane) to give effect to the rights set out in those treaties. Thus, the High Court concluded:

Where there are two possible interpretations of the word "parent" in Article 12(4) of the Federal Constitution, the interpretation that best promotes our commitment to international norms and enhance basic human rights and human dignity is to be preferred. Where a particular interpretation makes the right of the equal rights of the mother with the father where guardianship is concerned under the Guardianship of Infants Act 1961, illusory and infirm, then an interpretation that is consistent with international human rights principle must be invoked to infuse life into it. ${ }^{58}$

Although not specifically couched in legitimate expectation language, the High Courts' reference to how international obligations could directly create domestic obligations approximates and could suggest an underlying

57 Indira Gandhi A/P Mutho v. Pengarah Jabatan Agama Islam Perak, [2013] 5 Malaysian LaW Journal 552 (Malay.) [hereinafter Indira Gandhi].

Id. 
acceptance of the doctrine. It remains to be seen if this jurisprudence would take root and be applied in future cases. Nonetheless, it should be noted that the High Court in Indira Gandhi also relied heavily on Noorfadilla, which I will discuss in the next section on interpretive incorporation.

\section{d. Interpretive Incorporation}

Of the three types of human rights argumentation, interpretive incorporation has been most successfully employed in domestic courts. Among the various cases where international human rights norms have been invoked to support judicial interpretation is a 2001 seminal decision on indigenous rights. In Nor Anak Nyawai v. Borneo Pulp Plantation, the High Court of Kuching referred extensively to the United Nations' Draft Declaration on the Human Rights of Indigenous Peoples to support recognition and upholding of the plaintiffs' native customary right over parts of land in Sarawak. ${ }^{59}$ Although the judge was careful to add that the draft declaration played "no part" in his decision because "they do not form the law of the land," the declaration's provisions were clearly important for reinforcing the judge's censure of the defendant's treatment and attitude towards the plaintiffs. ${ }^{60}$ As the court recognized, the draft Declaration was a reflection of global attitude and thus was an important resource in interpreting the protections envisaged under the Federal Constitution for natives of Sabah and Sarawak. ${ }^{61}$

The use of human rights declarations to reinforce a judicial decision was also present in the 2008 case of Abd Malek bin Hussin v. Borhan bin Hj Daud, ${ }^{62}$ where the High Court of Kuala Lumpur referred to the UDHR to support a robust reading of a constitutional guarantee of the right to be informed of the grounds for a person's arrest, as well as the right to counsel. ${ }^{63}$ This case was a tort claim for false imprisonment, assault, and battery against the police. In ruling that the arrest was unlawful, Justice

59 Nor Anak Nyawai v. Borneo Pulp Plantation, [2001] 6 Malaysian Law Journal 241 (Malay.) [hereinafter Nor Anak Nyawai].

$60 \quad I d$. at 298.

61 Id. at 297; see also Malay. Const. art. 161A.

62 Abd Malek bin Hussin v. Borhan bin Hj Daud, [2008] 1 Malaysian Law Journal 368 (Malay.) [hereinafter Abd Malek bin Hussin].

63 See Malay. Const. art. 5(3). 
Hishamudin opined that " $[\mathrm{t}]$ he preservation of the personal liberty of the individual is a sacred universal value of all civilised nations and is enshrined in the [UDHR]."64 Thus, the judge relied on the UDHR to reinforce his decision that the arrest was unlawful.

Finally, Noorfadilla is to-date the most significant case for interpretive incorporation. The plaintiff, Noorfadilla, had applied for and was offered employment as a relief teacher by a local district education office. After she attended a briefing and received placement in a local school, she was asked whether she was pregnant, to which she answered in the affirmative. The briefing officer then proceeded to withdraw her appointment. The Ministry of Education later admitted that it had a policy of not employing pregnant women as relief teachers because they were deemed to be less reliable ("may not frequently be able to attend to her job due to various health reasons") and they would need maternity rest ("the period between the time of delivery to full health is too long (two months)"). Thus, hiring them would be economically inefficient ("when she gives birth she needs to be replaced by [a] new teacher who will require further briefings"). The High Court decided in the applicant's favor, declaring that the Ministry's refusal to employ women as relief teachers on the basis of their pregnancy, as well as the revocation of the plaintiff's appointment in this instance was unconstitutional under Article 8(2) of the Federal Constitution. This article prohibits gender discrimination in the appointment of any office or employment by a public authority. Arguably, the case could have been adequately determined on the basis of Article 8(2). Pregnancy discrimination is clearly gender discrimination since it treats women differently and unequally from men. But the judge relied extensively on CEDAW to make this point. The link between Article 8(2) and CEDAW was derived from the fact that the constitution was amended in 2001 to include gender as an additional prohibited basis for discrimination with the stated aim of complying with the country's CEDAW obligations. ${ }^{65}$ Not only does Article 1 of CEDAW provide a broad definition of discrimination against women, Article 11(2) (a) expressly provides that State parties shall take appropriate measure to prohibit, subject to the imposition of sanctions, dismissal on the grounds,

\footnotetext{
64 Abd Malek bin Hussin, supra note 62, at 383; See also Borhan bin HjDaud v. Abd Malek bin Hussin, [2010] 6 Malaysian LaW Journal 329 (Malay.) (overturning the High Court's decision).

65 See Constitution (Amendment) (No. 2) Act (Act No. A1130/2001) (Malay.).
} 
inter alia, of pregnancy. CEDAW thus provides support for clarifying the meaning of gender discrimination under Article 8(2).

Unlike in SIS Forum, the High Court did draw a distinction between declarations and ratified treaties. It emphasized that CEDAW is not a mere declaration, but a convention, which means that it is binding on member states. ${ }^{66}$ The High Court drew from the Federal Court's decision in Mohamad Ezam, which stressed this distinction. The judgment further relied on a slew of state practices to show that Malaysia intends to comply with its CEDAW commitments. These include a letter affirming its commitments from the Permanent Mission of Malaysia to the Permanent Missions of the Members States of the United Nations dated 9 March 2010, parliamentary debates on the constitutional amendment, as well as the Malaysia's participation at the 1988 Bangalore meeting and the ensuing Bangalore Principles.

On this basis, the High Court determined that it had the "duty" to take into account Malaysia's commitment and obligations at the international plane, and therefore "no choice but to refer to CEDAW in clarifying the term "equality" and gender discrimination under Article 8(2) of the Federal Constitution."67

\section{e. Relevant and Superordinate to National Laws}

The cases discussed so far in this section demonstrate a mitigation of the strict dualist position. Although some courts still affirmed the strict dualist position represented by the absolute non-relevance proposition, many departed from this to engage with international human rights law. None of the cases discussed so far, however, went far as to also clearly depart from the propositions that domestic law prevails or constitutional law prevails. It is therefore interesting to note the 2011 case of Suzana Binti Md Aris v. DSP Ishak bin Hussain, which appears to go against even the mitigated dualist position that domestic law prevails. The facts of the case were rather extraordinary in the allegations of human rights abuse. It involved a claim of police abuse and negligence. The plaintiff's husband died while in police custody and it transpired that he was denied proper

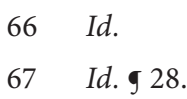


medical care and attention. ${ }^{68}$ The High Court found for the plaintiff. ${ }^{69}$ In the appeal on damages, the High Court increased the amount of damages assessed and added aggravated and exemplary damages. ${ }^{70}$ According to the Court, exemplary damages were necessary to reflect the seriousness of police conduct. ${ }^{71}$ Police officers had acted in such a way as to unlawfully deprive a person of his life. Furthermore, the Court opined that "[f] or the state to deprive a person of medical treatment promptly when he is in police custody, especially when he is in pain and vomiting blood, as in the instant case, is to subject the person to torture, cruel, inhuman or degrading treatment by default though not deliberately by design." 72

The interesting part of this judgment is that the High Court declared that the "UDHR is part and parcel of [Malaysia's] jurisprudence as the international norms in the UDHR are binding on all member countries." 73 There was a need to ground the court's decision to grant exemplary damages in international law because section 8(2)(a) of Malaysia's Civil Law Act $1956^{74}$ specifically prohibits the recovery of exemplary damages where a cause of action is brought by the estate of a deceased person. The court thus had to show that the police actions were especially egregious in the eyes of the law. This is where the UDHR comes in; Article 3 guarantees to every person the right to life, liberty, and security of person while Article 5 states that no one shall be subjected to torture or to cruel, inhuman or degrading treatment or punishment. The Court opined that any award for breach of "fundamental liberties" protected under the Federal Constitution (supposedly buttressed by the UDHR) stands on a separate head by itself. ${ }^{75}$ That the police had violated these provisions made their actions

68 Suzana Binti Md Aris v. DSP Ishak bin Hussain, [2011] 1 Malaysian Law Journal 107, 1-2 (Malay.) [hereinafter Suzana Aris].

Id. 32 .

$70 \quad I d$.

71 Id. 34.

72 Id. 24.

73 Id.

74 Civil Law Act (Act No. 67/1956) (Malay.).

75 Suzana Aris, supra note 68, at 34. 
particularly serious. Such human rights violations were thereby regarded as valid bases upon which to grant exemplary damages.

It must here be conceded that this case may be an outlier in the existing jurisprudence addressing the status of international human rights law in domestic courts. However, its jurisprudential value is substantial. It departs from the domestic law prevails proposition in asserting that international human rights law (even without a directly contradicting principle) can be used to overrule domestic law, which in this particular case was a domestic statute. This is a serious erosion of the dualist position since it accepts the direct application of international law in the domestic realm, and asserts a legal order where international law is hierarchically above domestic law. The court did concede however that the UDHR remains subject to the constitution. It may not be followed if the particular provision is "inconsistent" with a country's constitution. ${ }^{76}$

The resulting order is intriguing. The constitution, it would seem, is located at the top of this legal order, followed by international human rights law, and finally, domestic law. Since the UDHR is a declaration, which is deemed less binding than treaties, this suggests that under this legal schema, human rights treaties such as CEDAW and CRC should also take precedence over domestic law. Notably, this is a legal order consistent with section 4(4) of the SUHAKAM Act, which subjects the UDHR to the Federal Constitution (i.e. regard shall be had "to the extent that it is not inconsistent with the Federal Constitution"). This would be a significant incursion of dualist theory since international human rights law prevails over domestic law, and would be subject only to constitutional provisions.

\section{MITIGATED DUALISM}

\section{a. Relevance of International Human Rights Law}

One could surmise from the cases discussed in Part 4 that there is a fairly robust judicial trend in Malaysia repudiating the strict dualist position embodied by the absolute non-relevance of international law proposition. The cases show that international human rights law could be relevant for adjudication regardless of its source: whether it is derived from treaty obligations or from a widely accepted declaration. In this regard, section 
4(4) of the SUHAKAM Act is significant for asserting the relevance of the UDHR for the human rights commission, which has in turn opened the door for courts to accept UDHR as a source of law.

Theoretically speaking, the degree of relevance could differ depending on the source of human rights law. Whereas judges can more legitimately justify adopting human rights treaty principles on the basis that the state had explicitly ratified the treaty and the government cannot have intended not to comply with its treaty obligations, the justification for applying human rights declaration stands on less solid grounds. That said, a further distinction could be drawn between the UDHR and other declarations on account of the fact that the UDHR has attained the status of customary international law (which remains contested), or on the basis of section 4(4) of the SUHAKAM Act.

\section{b. Legal Status of International Human Rights Law in Malaysia}

Beyond the rejection of the first proposition of non-relevance, the status of international human rights law in Malaysia, whether subject to domestic law as a whole or only to the constitution, however is at a state of flux. If Suzana Binti Md Aris becomes firm precedent, international human rights law (even where derived from the UDHR) could prevail over national laws. This, as explained above, departs from the second proposition associated with dualism, which is that domestic law prevails over international law. This case however remains at the moment an outlier. Even Noorfadillla, which has been lauded for supposedly standing for the position that CEDAW is now binding law in Malaysia, does not, on a close reading, go so far as to support the priority of international human rights treaties over domestic law. This is because the court's decision was squarely based on its interpretation of the constitution. The invalidation of the ministerial decision and the underlying discriminatory administrative policy was based on inconsistency with the constitution's gender discrimination provision. ${ }^{77}$

One reading of Noorfadilla would hold that Article 8(2) of the Federal Constitution effectively incorporated the entirety of CEDAW into Malaysian law. In other words, Article 8(2) must be read as an incorporating law and that through this, CEDAW has been domesticated into the Malaysian legal system. This however falls back on the dualist structure: 
international law has to be specifically incorporated in order to have legal force in domestic law. Even this reading of Noorfadilla would be limited by current jurisprudence. This is because the extent of incorporation would be constrained by the text and scope of the constitutional provision. CEDAW provisions are incorporated only insofar as they fall within the purview of the constitutional provision.

This explains why the court in Noorfadilla was more willing to accept that there was gender discrimination that could attract judicial sanction in this case, and not in Beatrice Fernandez. Article 8(2) applies only to public actors, which the defendants were in Noorfadilla. However, Beatrice Fernandez involved a private corporation, and this may explain why the Federal Court did not consider CEDAW norms relevant in that case despite the arguments raised on the basis of Article 8(2). A private actor is not subject to its prohibition against gender discrimination. Clearly, if CEDAW had been incorporated wholesale, such a distinction would not matter since CEDAW does not admit a distinction between public and private actors when it comes to discrimination. This public-private distinction could be at the heart of another 2012 case where the Federal Court refused leave to appeal by female employees who claimed gender discrimination because the employer stipulated a lower retirement age for female employees. ${ }^{78}$ As such, the argument that CEDAW is directly applicable and could be used to invalidate domestic law and policy (including administrative action) remains unproven. ${ }^{79}$

A consistent reading of the cases would locate the source of this judicial overruling in Noorfadilla to the constitution. If gender had not been included as a prohibited basis for discrimination, the legal basis for invalidating the ministerial decision on grounds of gender/pregnancy discrimination would have stood on less solid grounds. CEDAW principles

78 Female Workers Refused Leave To Appeal, Straits Times (Aug. 14, 2012), http://www.nst.com.my/nation/ general/female-workers-refused-leave-toappeal-1.124800 (explaining that while male employees could work till they were 55 , female employees had to retire at 50).

79 For this reason, the Malaysian Bar has called upon the government to pass specific legislation prohibiting gender discrimination by both public and private entities. Press Release: A Right Step in a Long and Unfinished Journey, The Malaysian BAR (June 30, 2013), http://www.malaysianbar.org.my/press_statements/ press_ release_a_right_step_in_a_long_and_unfinished_journey.html. 
gave specific content and meaning to gender discrimination prohibited under Article 8(2) of the Federal Constitution. As such, the Noorfadilla case suggests that human rights treaty law could be a source of norms for constitutional interpretation. While it has departed from the absolute non-relevance proposition, Noorfadilla did not go as far as the Suzana case to stand for the position that international law could directly invalidate domestic law, thereby abandoning the domestic law prevails proposition.

\section{CONTEXTUALIZING MITIGATED DUALISM}

\section{a. Transnational Judicial Dialogue}

The cases show that Malaysia's courts are still working within the structure of dualism, but this has been mitigated to some extent by the departure from the strict position of absolute non-relevance of international law. This coincides with a broader shift in Malaysia's political climate towards increased state engagement with international and regional human rights discourse. Another crucial factor for this shift is the growing transnational judicial dialogue of which Malaysian judges are a part. On a whole, judges who find themselves increasingly engaged in transnational dialogue with judges in other jurisdictions, realize that categorically rejecting international law, particularly international human rights law, may lead to criticisms of provincialism. ${ }^{80}$

Now, commonwealth judges adjudicating over legal systems with a shared heritage in the English common law have always been part of a transnational dialogue. Referring to and referencing judicial opinions from other parts of the Commonwealth remains a common practice. The "new" development however is the broadening of this transnational dialogue to global and international actors. Judges from legal systems that do not share a common legal heritage now find themselves in conversation with each

80 This is part of a broader debate about the relevance of foreign law in domestic case. Justice Scalia of the Supreme Court of the United States is one of the most vocal opponents of this broad transnational trend in judicial reasoning. Sosa v. Alvarez-Machain, 124 S. Ct. 2739, 2776 (2004) (Scalia, J., concurring) (decrying the use of foreign state practices (forming the basis of customary international law) stating " $[\mathrm{t}]$ he Framers would, I am confident, be appalled by the proposition that, for example, the American people's democratic adoption of the death penalty ... could be judicially nullified because of the disapproving view of foreigners."). 
other and with international actors. ${ }^{81}$ Furthermore, as Gerald Neuman observes, the postwar development of international human rights law has widened the field for interaction between international law and constitutional interpretation. ${ }^{82}$ Thus, judiciaries that insist on categorically rejecting international law risk being perceived locally and globally as overly statist, parochial, and perhaps somewhat archaic in today's climate. This may explain why instead of dismissing outright the relevance of international human rights law, many judges now assert instead that international law is still subject to the constitution and other domestic laws. This way, judges are able to defend local sovereignty and autochthony without appearing antiquated to the transnational judicial community.

Categorical rejection of international law is furthermore less appealing for Malaysian judges when even commonwealth judges, who are conventionally committed to strict dualism, have moved beyond this position. As Waters points out, judges in many dualist countries are increasingly implementing and entrenching their nations' international treaty obligations into domestic law, thus becoming powerful domestic enforcers of international human rights law. ${ }^{83}$ She calls this trend "creeping monism." 84 This refers to the abandonment among common law courts of their traditional dualist orientation in favor of utilizing unincorporated human rights treaties in their work despite the absence of legislation giving domestic legal effect to such treaties. ${ }^{85}$ It entails developing a more flexible conception of the role of such treaties in interpreting domestic legal texts. ${ }^{86}$ Judges engaged in this transnational shift no longer treat unincorporated human rights treaties as having no domestic legal effect, but have developed a wider range

81 For instance, the Yale Law School's annual Global Constitutionalism was a forum aimed at fostering such transnational dialogue on constitutional law.

82 Gerald L. Neuman, The Uses of International Law in Constitutional Interpretation, 98 American Journal of International LAW 82, 84 (2004).

83 Melissa A. Waters, Creeping Monism: The Judicial Trend Toward Interpretive Incorporation of Human Rights Treaties, 107 Columbia Law Review 628, 633-34 (2007).

84 Id. at 633.

85 Id.; see also Michael Kirby, The Impact of International Human Rights Norms: 'A Law Undergoing Evolution,' 25 Western Australian Law Review 130 (1995).

Waters, supra note 83, at 635. 
of interpretive incorporation techniques to utilize treaties in domestic adjudication. ${ }^{87}$

An important forum for transnational dialogue among Commonwealth judges is a series of Judicial Colloquiums held between 1988 and 1998. Organized by the human rights non-governmental organization Interights and the British Commonwealth Association (an intergovernmental organization representing fifty-three Commonwealth member states), these colloquia have been instrumental in creating a common aspiration among common law judges to develop and advocate judicial principles that take a more robust view of judicial role in protecting rights. The most prominent set of principles were the ones declared in 1988 at the conclusion of the Judicial Colloquium held in Bangalore, India. These are the 1988 Bangalore Principles, referred to above. Nonetheless, while the Principles declare that national courts should "have regard to international obligations," they also state that:

[W] here national law is clear and inconsistent with the international obligation of the state concerned, in common law countries the national court is obliged to give effect to national law. In such cases the court should draw such inconsistency to the attention of the appropriate authorities since the supremacy of national law in no way mitigates a breach of an international legal obligation which is undertaken by a country. ${ }^{88}$

The 1988 Bangalore Principles therefore entail balancing the conventional and limited role of the judiciary in implementing human rights treaties with the judicial impetus to protect individual human rights from state violations. On the one hand, judges affirm the primacy of domestic law (and implicitly, parliament's role in incorporating international law). On the other hand, judges assert a public policy (which judges are bound to uphold) to give effect to clearly established rules of international law and, to the extent possible, interpret legislation so as to avoid a conflict with international law. ${ }^{89}$ This rests on a legal fiction, that there is "prima facie presumption that Parliament does not intend to act in breach of interna-

\footnotetext{
$87 \quad I d$. at 636.

881988 Bangalore Principles, supra note 40.

89 Malcolm Shaw, International Law 139, 153 (6th ed. 2008).
} 
tional law, including therein specific treaty obligations." ${ }^{00}$ Thus, although the 1988 Principles provided a normative appeal for a judicial role in incorporating international law, this is still limited by the need to respect the doctrine of the separation of powers and the proper role of parliament.

In contrast, the 1998 Colloquium went further in conceptualizing the judiciary as having an even more robust role in achieving human rights. By 1998, commonwealth judges have come to see themselves as more central to the realization of human rights. ${ }^{91}$ The colloquium concluded with the statement that takes an even more assertive view of judicial function:

[F]undamental human rights form part of the public law of every nation, protecting individuals and minorities against the misuse of power by every public authority and any person discharging public functions. It is the special province of judges to see to it that the law's undertakings are realized in the daily life of the people. ${ }^{92}$

This judicial theory sees human rights as a normative framework which judges are bound to apply. It sees judges as not only operating within the domestic system but also as engaging in the international sphere. Judicial interpretation is thus aimed at achieving substantive convergence between the domestic legal system and the international human rights system. ${ }^{93}$ This suggests that international human rights law is the "primary, authoritative

90 Salomon v. Comm'r of Customs and Excise, [1967] 2 Q.B. 116, 143 (Eng.).

91 Waters, supra note 83, at 648.

92 Commonwealth Secretariat, Developing Human Rights Jurisprudence Vol. 8: Eighth Judicial Colloquium on the Domestic Application of International Human Rights Norms 267-70 (2001); see also Lord Lester of Herne Hill QC, The Challenge of Bangalore: Making Human Rights a Practical Reality, 25 Commonwealth Law Bulletin 47 (1999).

93 See Vicki Jackson, Constitutional Comparisons: Convergence, Resistance, Engagement, 119 Harvard Law Review 109 (2005). It should be noted that treating unincorporated human rights treaties as soft law or hard law can conform to the view that convergence with international law (and laws of other nations) is desirable. This is what Jackson has called the Convergence Model that the constitution is best viewed as a site for implementing international law or for the development of transnational norms. 
source for human rights" and that domestic law is "merely derivative of international human rights law."94

The influence of the 1988 Bangalore Principles can be discerned from the High Court decision in Noorfadilla where the High Court referred the principles in support. As the Court noted: "The Chief Justice of Malaysia at that time was one of the participants of the colloquium." 95 This served to reinforce the Court's determination that it is part of its judicial obligation to have regard to Malaysia's obligations under CEDAW in defining equality and gender discrimination under Article 8(2) of the Federal Constitution. ${ }^{96}$

Notably, the Bangalore Principles were first agreed to in 1988, more than twenty years before Noorfadilla was decided. The delayed acceptance and influence of these principles could be attributed to the constitutional crisis that thrust the Malaysian judiciary into a state of disarray in 1988. This was the year when the Malaysian judiciary became embroiled in a clash with the executive under then Prime Minister Mahathir Mohammad's administration. It is widely known that the executive was reacting to a series of public law cases that went against the interests of the ruling party. As the judiciary fought off executive interference and sought to assert its independence, this led to an executive maneuver for an inquiry into alleged judicial misconduct. ${ }^{97}$ It was a clash that the judiciary lost; the Lord President and two Supreme Court judges were unceremoniously removed from office. ${ }^{98}$ Three other Supreme Court judges were suspended but later reinstated. It is notable that Malaysia's representative at the 1988 Bangalore Colloquium was Tun Salleh Abas, the Lord President who was removed

94 Waters, supra note 83, at 648.

95 Noorfadilla, supra note 3, at 25.

96 Id. 26.

97 V. Sinnadurai, The 1988 Judiciary Crisis and its Aftermath, in ConstitutionaL Landmarks in Malaysia: The First 50 Years 1957-2007 173 (Andrew Harding \& H. P. Lee eds., 2007); Khoo Boo Teik, Between Law and Politics: The Malaysian Judiciary since Independence, in Law, Capitalism and Power in Asia: The Rule of LAW AND Legal Institutions (Kanishka Jayasuriya ed., 1999).

98 Tun Mohamed Salleh Abas, May Day for Justice (1989); Andrew Harding, The 1988 Constitutional Crisis in Malaysia, 39 International and Comparative LaW Quarterly 57 (1990). 
in this crisis. ${ }^{99}$ The Malaysian judiciary did not participate in subsequent years. ${ }^{100}$ As mentioned, the last commonwealth judicial colloquium in this series was in $1998 .{ }^{101}$

The recent revival of the Bangalore Principles and the restoration of the sense of transnational judicial dialogue could be a sign that the judiciary is emerging from this period of crisis. In 2008, a Panel of Eminent Persons cleared the removed Supreme Court judges of any wrongdoing. ${ }^{102}$ The Panel concluded that there was no cogent material available to frame a triable charge against the Lord President, Tun Salleh Abas. Not only was the Lord President declared innocent of the charges against him, he was also deemed to have been performing his constitutional duty to uphold and protect the doctrine of separation of powers and the rule of law. ${ }^{103}$ It should be noted that this was not an official panel - the Malaysian government repeatedly refused to open an official inquiry into the incident - but was jointly established by the Malaysian Bar Council, the International Bar Association, Lawasia, and Transparency International. The Panel's conclusions were however crucial in restoring the reputations of the respective judges,

99 See Commonwealth Secretariat, Developing Human Rights Jurisprudence Vol. 7: Seventh Judicial Colloquium on the Domestic Application of International Human Rights Norms 217-18 (1998).

100 Id. at 219-37. In 1989, the judicial colloquium was held in Harare, Zimbabwe, and resulted in the Harare Declarations of Human Rights. The 1990 judicial colloquium was held in Banjul, The Gambia, and concluded with the Banjul Affirmation. In 1991, the judicial colloquium took place in Abuja, Nigeria, resulting in the Abuja Confirmation. The Baliol Statement of 1992 came out of the 1992 judicial colloquium in Oxford, whereas the 1993 judicial colloquium took place in South Africa and concluded with the Bloemfontein Statement. The 1996 judicial colloquium was held in Guyana, and produced the Georgetown Conclusions.

101 See Commonwealth Secretariat, supra note 99, at ix-x. The last judicial colloquium in this series was held in 1998 in Bangalore, India. Judges from Australia, Bangladesh, Canada, India, New Zealand, Pakistan, South Africa, Sri Lanka, Uganda, United Kingdom, USA and Zimbabwe attended.

102 Report of the Panel of Eminent Persons to Review the 1988 Judicial Crisis in Malaysia, The Malaysian Bar (July 26, 2008), http://www.malaysianbar.org.my/index. php?option=com_docman\&task=doc_view\&gid=1715\&Itemid=332.

103 See Mahalethchumi Balakrishnan, Panel of Eminent Persons Report on the 1988 Judicial Crisis in Malaysia, The Malaysian Bar (Sept. 2, 2008), http://www. malaysianbar.org.my/bar_news/berita_badan_peguam/panel_of_eminent_ persons_report_on_the_1988_judicial_crisis_in_malaysia.html. 
and, possibly, rebuilding the dignity of the judiciary in the long run. One significant observation to be made from this is also the self-appointed role of the Malaysian Bar Council in not only upholding judicial independence and the rule of law as core values of the Malaysian legal system, but, as the next section demonstrates, also of human rights in general.

Further evidence that the Malaysian judiciary may be recovering from the traumatic period of the constitutional crisis can be seen in its participation in a 2009 Judicial Colloquium on the Domestic Application of International Human Rights Norms in Bangkok, Thailand. Convened by the Office of the United Nations High Commission for Human Rights, participants at the colloquium referred to the 1998 Bangalore principles and subsequent outcomes on the commonwealth judicial colloquia, and affirmed that:

[J]udiciaries should consider referring, where pertinent, to the jurisprudence of the UN human rights treaty bodies and of the regional human rights mechanisms, in interpreting the international human rights treaties binding their States and their domestic Constitutions and Bills of Rights protecting these rights. ${ }^{104}$

The Chief Justice of Malaysia led the Malaysian delegation. ${ }^{105}$ This resumption of participation in the transnational judicial dialogue after a long period of disengagement is significant.

\section{b. Malaysian Lawyers and Human Rights Advocacy}

Another crucial factor in the rise in human rights discourse and the mitigation of strict dualism in the courts is the instrumental role of the Malaysian Bar Council in mainstreaming human rights among lawyers and the public. This should, at least partially, account for the increase in human rights arguments being raised in the courts over the last decade. The Bar Council's Human Rights Committee, for instance, expressly aims to "[i]ncrease the level of awareness and education of human rights norms

104 The Office of the United Nations High Commissioner for Human Rights, Judicial Colloquium on the Domestic Application of International Human Rights Norms 4 (Mar. 23-25, 2009), www2.ohchr.org/ english/bodies/docs/Bangkok_ declaration_23-25march09.doc.

105 This was the then Chief Justice Tan Sri Dato' Seri Zaki bin Tun Azmi, who was accompanied by two Court of Appeal Judges, a High Court Judge, and a Judicial Commissioner of the High Court. 
within the Malaysian Bar and the public" and it does so through a range of advocacy, monitoring, and training activities. ${ }^{106}$ It has been an active participant in monitoring Malaysia's human rights treaty obligations, noting for instance when periodic reports are due under CEDAW and the CRC, and in making submissions to the Human Rights Council as part of the Universal Periodic Review process. ${ }^{107}$ These efforts create an awareness and understanding among lawyers and the public of Malaysia's human rights obligations, and empower them to bring or substantiate legal claims with arguments premised upon international human rights law.

As Harding and Whiting highlight, Malaysian lawyers have been able to mobilize and sustain efforts to defend civil and political rights as well as other core values commonly underlying liberal legal systems (such as the rule of law, the independence of the judiciary, and the integrity of the constitution and of constitutional government). ${ }^{108}$ Harding and Whiting identify five reasons for this. First, they argue, Malaysian lawyers have been able to preserve the Bar's corporate autonomy, and resist state interference in its self-governance. ${ }^{109}$ Secondly, they contend that Malaysian lawyers have been able to forge crucial alliances with civil society advocacy groups and use mass media (particularly new digital media) effectively. The third reason Harding and Whiting identify is the "cultural orientation of common lawyers to liberal 'legalism." "110 A fourth reason is that since civil and political rights are constitutionally guaranteed, lawyers are in a position to frame social and political conflict in legal terms, specifically in terms

106 For an overview of the range of activities, see Malaysian Bar Council, Human Rights Committee: 2012/2013 Annual Report, The Malaysian Bar (2013), http://www.malaysianbar.org.my/index.php?option=com_docman \&task=doc_ view\&gid $=4125$.

107 See for instance, Malaysian Bar Council, Submission of Bar Council Malaysia for the Universal Periodic Review of Malaysia 2013, The Malaysian Bar (2013), http://www.malaysianbar.org.my/index.php?option= com_docman\&task=doc_ view\&gid=4096\&Itemid=332.

108 Andrew Harding \& Amanda Whiting, Custodians of Civil Liberties and Justice in Malaysia: The Malaysian Bar and the Moderate State, in Fates of Political Liberalism in the British Post-Colony: The Politics of the Legal Complex 247 (Terence C Halliday et al. eds., 2012) available at http://www.law.unimelb. edu.au/ files/dmfile/CustodiansofCivilLibertiesandJustice20122.pdf.

109 Id. at 298.

$110 I d$. 
of constitutional rights and their violations. Lastly, the politicization of a broad range of policy issues has magnified the importance of constitutional litigation as it "shifts social and political disputes into courts and translates them in lawyerly parlance of due process."111

This is especially consequential and confirms Bruce Ackerman's observation that the transformation of the professional culture is most crucial to successful social movements. Empirical evidence, he argues, shows that "the mobilization of a powerful movement for constitutional change is neither necessary nor sufficient for large doctrinal changes" in courts. ${ }^{112}$ Instead, Ackerman observes that successful social movements have to change the political culture and, through it, the professional culture.

Indeed, the Bar Council's close alliance with civil society organizations to monitor, critique, and lobby the government on has also contributed to a strengthened human rights movement in Malaysia. ${ }^{113}$ This movement operates on multiple fronts, encompassing a wide range of NGOs, the Bar Council, as well as the human rights commission (SUHAKAM). ${ }^{114}$

111 Id.

112 Although he speaks of the Supreme Court of the United States, this insight is generalizable for other constitutional systems, especially in common law jurisdictions that follow the doctrine of stare decisis. Bruce Ackerman, Interpreting the Women's Movement, 94 California Law Review 1421, 1424 (2006).

113 Whiting for instance has mapped out a constructive cooperation between the Bar Council with human rights and women's organizations in law reform. Amanda J. Whiting, Secularism, the Islamic State, and the Malaysian Legal Profession, 5 Asian Journal of Comparative Law 18-19 (2010). See Joint Statement by COMANGO, JOAS and Bar Council Human Rights Committee - More Attention and Action Needed on Human Rights, The Malaysian Bar (Oct. 28, 2013), http://www.malaysianbar.org.my/human_rights/joint_statement_by_comango _joas_and_bar_council_human_rights_committee_more_attention_and_ action_needed_on_human_rights.html_for an example of such cooperation.

114 See Meredith L. Weiss, The Malaysian Human Rights Movement, in SociaL Movement in Malaysia: From Moral Communities to NGOs 140 (Meredith L. Weiss \& Saliha Hassan eds., 2003); see also Asian Human Rights Charter, May 17, 1998, available at http://www.refworld.org/pdfid/452678304.pdf. While these various human rights actors have diffused and divergent goals, they share a common ground in their endorsement of the UDHR. For instance, several NGOs endorsed a Malaysian Charter on Human Rights in 1999 which enumerates a broad range of civil and political rights due to Malaysians, which is based primarily on the UDHR as well as the Asian Human Rights Charter. 
Cooperation and support among these organizations is especially crucial considering the tight restrictions on freedom of assembly, speech, and the press. ${ }^{115}$ As Weiss highlights, civil society organizations "have played a key role in exploring and espousing political, social and economic reforms, in the process sustaining a nucleus of committed activists."116

Thus, the rise in human rights discourse and the increasing acceptability of human rights argumentation in Malaysian courts can be attributed to a large extent to the involvement of Malaysian lawyers increasingly familiar with international human rights norms, whether by virtue of the work of the Malaysian Bar Council or through collaboration with civil society organizations involved in human rights work.

\section{CONCLUSION}

In conclusion, there has been increased engagement with human rights norms in Malaysian courts. Although the results are mixed, with the court accepting the direct application of human rights law in some cases and rejecting it in other cases, it is at least clear that the strict position of absolute non-relevance has now given way to the intermediate position characterized by the proposition that domestic law (and constitutional law) prevails. Whether this greater openness towards international human rights law will be sustained and whether it could further influence legal interpretation depends to a large extent on judicial self-definition and on the involvement of Malaysian lawyers in strategic litigation. Borrowing from Ignatieff's still apposite observation, the success of global human rights movement lies in its ability to go local. ${ }^{117}$ The ability to sustain efforts to domesticate human rights law in local courts is crucial to this process.

115 See Meredith L. Weiss, Edging Toward a New Politics in Malaysia: Civil Society at the Gate?, 49 Asian Survey 741 (Sept./Oct. 2009), for discussion examining the role of civil society in bringing about political changes and noting the "sheer scale" of civil societal involvement in the 2008 general elections.

116 Meredith L. Weiss, Malaysian NGOs; History, Legal Framework, and Characteristics, in Social Movement in Malaysia: From moral communities to NGOs 42 (Meredith Weiss \& Saliha Hassan eds., 2003).

117 Michael Ignatieff, Human Rights as Politics \& Idolatry 70 (1999). 